\title{
Ordu kenti kentsel peyzaj karakter analizi*
}

\section{Ömer ATABEYOĞLU' ${ }^{1}$ Yahya BULUT²}

\author{
1 Ordu Üniversitesi Ziraat Fakültesi Peyzaj Mimarlı̆̆ı Bölümü Cumhuriyet Yerleşkesi, ORDU \\ ${ }^{2}$ Atatürk Üniversitesi Mimarlık ve Tasarım Fak. Peyzaj Mimarlığı Bölümü, ERZURUM
}

\begin{abstract}
*Bu çalışma 2011 yılında tamamlanan “Ordu Kenti Yapısal Peyzaj Karakter Analizi ve Kentsel Planlama Stratejileri” isimli doktora tezinin
\end{abstract} bir kısmıdır.

Alınış tarihi: 25 Eylül 2012, Kabul tarihi: 22 Mart 2013

Sorumlu yazar: Ömer ATABEYOĞLU, e-posta: atabey6@hotmail.com

\section{Özet}

Kırsal ve kentsel peyzajlar çeşitli faktörlerin etkisiyle şekillenirler. Bu peyzajların özellik ve değerlerinin tespiti peyzajların kullanımlarını yönlendirmektedir. Bu çalışmada Ordu kenti için kentsel yapısal peyzaj karakter analizi gerçekleștirilmiștir. Çalıșmanın materyalini Ordu kenti olușturmakta olup, mücavir alan sınırları ile sınırlandırılmıștır. Çalışmada Coğrafi Bilgi Sistemleri (CBS) ile veri işlenmesi sonucu elde edilmiş haritalar ve haritalardan elde edilmiş çeşitli istatistiklere dayalı peyzaj karakter analizi yöntemi kullanılmıştır.

Çalışmanın amacı, kentin yapısal mevcut durumunun ortaya koyulması ve kente ilişkin verilerin derlenmesi sonucunda kentin gelecek gelişim planlarına yön verilmesi ve planlama alt yapısı hazırlamaktır.

Anahtar kelimeler: Ordu, peyzaj karakter analizi, peyzaj mimarlığı, kentsel planlama

\section{Landscape character analysis of Ordu city}

\begin{abstract}
Urban and suburban landscapes shape with effect of various factors. Determination of properties and values of these landscapes directs usage of landscapes. In this study was studied the analysis of urban structural landscape character for Ordu City. Material of the study is boundary of municipality of Ordu City. In the study was used method of analysis
\end{abstract}

of landscape character based on statistics in maps and maps that data was processed with GIS.

Aim of the study is prepare substructure for planning and development plan of the city on result of determination of current situation of the city and collect of data on the city.

Key words: Ordu city, landscape character analysis, landscape architecture, urban planning

\section{Giriş}

Mevcut bulunan her canlı ve cansız, insan, hayvan, doğa parçası, yapı, eser, nesne ve benzeri daha pek çok şey bir karaktere sahiptir. Bu karakterler onları benzerlerinden ve diğer her şeyden ayırt eder, farklı kllar, öne çlkartır ve gruplandırır, eşleştirir. Bu haliyle değerlendirildiğinde ister doğal ister kültürel olsun peyzajlar için de karakterden söz edilebilir.

$\mathrm{Bu}$ nedenle son yıllarda peyzaj alanlarına ilişkin karakter tespit çalışmaları yaygınlaşmış ve önem arz eder hale gelmiştir. Zira peyzaj karakterinin tespiti gerek doğal, gerek kültürel alanlarda olsun, kırsalın ve kentin güncel değerinin, kullanımlarının, değerlendirilme olanakları ile potansiyellerinin belirlenmesine olanak sağladığı gibi aynı zamanda geleceğine ilişkin plan kararlarının belirlenmesine ve dolayısıyla kırsalın veya kentin gelecekteki gelişim, değişim ve yönelimi üzerine de etkin rol oynamaktadır.

Peyzaj karakteri, kırsal ve kentsel alanların öne çıkan, onları diğerlerinden farklı kılan, kentin gelişim ve değişimine yön verebilecek nitelikteki verileri 
sunan değerler bütünüdür. Daha başka tanımlamalara göre peyzaj karakteri;

Bir peyzajı diğerinden ayıran, iyi veya kötü olduğu yargısına ulaştıran, belirgin, tanınabilir ve sürekliliği olan özelliğidir (Atik ve Ortaçeşme 2010).

Peyzaj karakteri; çevremizdeki alanları anlayabilmemizi sağlayabilen, farklı bileşenlerin (jeoloji, topoğrafya, toprak, bitki örtüsü, alan kullanımları, yerleşim yerleri, vb.) farklı kombinasyonlardan ortaya çlkan bir desendir (Swanwick, 2002). Peyzaj karakteri bir peyzajı iyi ya da kötü diye nitelendirmek yerine, onu diğerinden farklı kılan peyzaj öğelerini tarif eder. Kısaca peyzaj karakteri bir alanı benzersiz kllan özelliktir (Wascher, 2005; Özgür 2011)

Peyzaj alanlarının karakterlerinin belirlenmesi ise önemli bir süreçtir. Gözlemler, alan değerlendirmeleri ve temin edilen ve çalışmalarla tespit edilen istatistiki veriler bu karakter tahliline yön verir, yapılan peyzaj karakter analizi ise sonucu teşkil eder.

Farklı, ayırt edici özelliği olan alanların, peyzajların tanımlanması, sınıflandırılması ve haritalanmasına peyzaj karakter analizi denilir (Atik ve Ortaçeşme 2010). Peyzaj Karakter Analizi ile peyzaj içindeki doğa ve insan eliyle oluşturulmuş öğelerin uyumu, tarihi, estetik, etnolojik veya antropolojik olarak taşıdığı değer, o bölgedeki hakim doğa unsurları, arazi kullanım biçimleri, geleneksel yaşamın sürdüğü dokuların bir bölgeyi veya yöreyi temsil etme durumu gibi doğal, kültürel, sosyo-ekonomik, tarihi özellikleri sorgulanmaktadır (Atik ve Ortaçeşme 2010).

Planlama ve tasarım disiplinlerinin peyzaj karakterine yaklaşımları farklıdır. Peyzaj karakterini belirleyen etmenler planlama başlığı altında daha çok sayısallaştırma, haritalama vb. ile irdelenmektedir (Özgür, 2011).

Kentsel mekanların peyzaj karakterlerinin değerlendirilmesinde kentsel faktörlerin çeșitliliği, miktarı, dağılımı, yeterliliği, estetik değeri, kentsel katkısı gibi özellikler ön plana çıkmaktadır. Mevcut durum analizleri ve haritalama çalıșmaları ile önerilere dönük analizleri ve haritalandırma çalışmaları kentsel yapısal karakter analizinin temelini oluşturmaktadır.

Çalışmada amaç, peyzaj karakter analizi alanında çok daha az gündeme gelen, çok az çalışılmış, oldukça az literatüre sahip, çalışılması kısıtlılık gösteren ve üzerindeki insan yapısı faktörler nedeniyle çeşitlik ve sürekli değişim gösteren kentsel mekanların karakter analizi konusuna katkı sağlamak ve yeni açlımlar getirmektir. Daha özelde amaç, Ordu kenti mücavir alan sınırları içerisinde ve kente ait mevcut alan kullanımlarının, niteliklerinin ve dağılımlarının ortaya koyulması, bu kapsamda kentteki yeşil alan varlığı, fonksiyon çeşitliliği ve yeterliliğinin tespit edilmesi, kentin yapısal peyzaj karakter analizinin gerçekleştirilmesi sonucunda "Coğrafi Bilgi Sistemleri" ile haritalarının oluşturulması, kent planlamasına ilişkin stratejiler ile haritalarının verilmesi ve kentsel yönelimlere ilişkin çalışma altlı̆̆ı olușturmaktır.

\section{Materyal ve Yöntem}

Çalışma alanı olarak seçilen ve Karadeniz Bölgesi Doğu Karadeniz bölümünde yer alan Ordu ili, kuzeyde Karadeniz, güneyde Sivas ve Tokat, batıda Samsun, doğuda ise Giresun illeri ile çevrelenmektedir. (Anonim, 2008). Toplam yüzölçümü $5961 \mathrm{~km}^{2}$ olup, üzerinden Melet, Civil Deresi, Akçaova Deresi gibi büyüklü küçüklü akarsuların oluşturduğu yer yer alüvyon düzlükler bulunmaktadır (Anonim, 2004).

Kent çevresini ise bir dizi tepe çevrelemektedir. Bu tepeler 180 ile 480 metre arasındaki yüksekliklere sahip olup, kentin kurulduğu ve mücavir alan sınırlarını olușturan yerleşim ise büyük çoğunlukla 0 ile $30 \mathrm{~m}$ rakım arasında yer almaktadır. Yerleşimi çevreleyen tepeler kenti Karadeniz kıyısı boyunca yayılmaya zorlamıştır. Çevredeki tepelerin çok yüksek rakımlı olmaması bir miktar yerleşim alanının bu tepelere doğru kaymasını engelleyememiştir.

2011 yılı verilerine göre, ilin toplan nüfusu 714 bin olup, bunun 409 bini il ve ilçelerde, 305 bini de belde ve köylerde yaşamaktadır. Kent nüfusu ise 140 bindir (Anonim, 2012). Kentte batıdan doğuya doğru dört farklı akarsu geçmektedir. Kent kuzeyden denizle sinırlanmakta olup, kıyı uzunluğu 20033 m'dir. Doğu, batı ve güneyden ise ormanlık alanlarla kaplı tepelerce çevrelenmiștir. Kentte, mücavir alan sınırları içerisinde nüfusları 482 ile 16947 kişi, alanları ise 8,9 ha ile 399,3 ha arasında değișim gösteren 26 adet mahalle bulunmaktadır.

\section{Yöntem}

Araştırmada, kompleks bir sistem olarak karşımıza çıkan kent kendisini oluşturan bileşenlerine, mahallelere ve mahallelerdeki alan kullanımlarına ayrıştırılarak incelenmiş, elde edilen parçalara ait 
veriler toparlanarak kentin geneline ve kentin planlamasına ait veriler elde edilmiştir.

Temin edilen verilerin değerlendirilmesi sırasında öncelikli olarak kent, mücavir alan sinırları içerisindeki 26 adet mahalleye ait alan kullanımları bakımından incelemeye alınmıştır. $\mathrm{Bu}$ aşamada Coğrafi Bilgi Sistemleri (CBS) ile öncelikli olarak temin edilmiş olan kente ilişkin sayısal topoğrafik harita üzerine AutoCAD ve NetCAD yazılımları ile 1/1000 ölçekli 107 parça imar paftaları üzerinden hazırlanan altlık CBS yazılımında düzeltilerek WGS_1984_UTM_Zone_37N koordinat sistemine göre dünya koordinatlarına yerleştirilmiştir. Çalışmada ArcGIS 9.0 programı ile temin edilen sayısal haritaların işlenmesi ve veri girişleri ile analizler ve yeni hedef haritaların oluşturulması işlemleri gerçekleştirilmiştir. Buna ilaveten VantagePoint yazılımı ile GPS aracılığıyla elde edilen noktasal verilerin işlenmesi, bilgisayar ortamına aktarılması, Harfa 5.3 yazlımından ise fraktal analizlerin gerçekleştirilmesi konularında faydalanılmıştır. Haritaların oluşturulmasının ardından mahallelere ait ve CBS ile elde edilmiş veriler grafiklere ve tablolara dönüştürülerek veriler sınıflandırılmış ve yorumlanmıştır.

Fraktal analiz yöntemi, uzaydaki tek, iki ve üç boyutlu nesneleri 1,2,3 gibi tam saylar yerine kesirli sayllarla ile ifade eden bir analiz yöntemidir. Kare sayma esasına dayanır. Kullanılan program ile görüntü siyah beyaz veriler şeklinde işlenir. Görüntü, program aracılığıyla siyah obje tarafından tamamen kapsanan siyah kareler (DB), siyah objeyle çakışan fakat tamamen siyah objeyle tamamen kaplı olamayan siyah-beyaz kareler (DBW) ve siyah objeyle çakışmayan beyaz objeler (DW) şeklinde sinıflandırılmaktadır. Temel görüntü, siyah-beyaz şeklindeki vektörel görüntü halinde analize hazırlanır. Analiz sonucunda fraktal yapının dağılımını gösteren grafik ile fraktal değer elde edilir. Bu değer büyüdükçe şeklin kompleksleştiği, estetik değerinin ve organik yapısının arttı̆̆ ve nesnenin uzaydaki oranın büyüdüğü, kentsel analizler için farklı perspektifler, mekan zenginliği ve görsel kalitenin arttığı anlaşırken, değer küçüldükçe bunun tam tersi anlaşılır. Kentsel çalışmalarda kentsel unsurların dağılımı, kentlerin ve unsurlarının karşılaștırması, yoğunluk, kentin kompleksitesi ve estetik potansiyeli gibi değerlendirmeler yapılabilmektedir.

Harfa programı ile elde edilen fraktal değer, seçilerek değerlendirmeye alınmış olan değer, siyah kareler (B) ve siyah-beyaz kareler (BW)'in toplamına ait değerdir. Bu nedenle analizde "B+BW", hassasiyet derecesi "0,001", korelasyon da ise kaynaklarca standart bir değer alınması uygun görülen " 0,9 " değeri alınmış ve analiz gerçekleştirilmiştir. Her mahallenin hem bütününe ilişkin, hem de yeşil alanlarına ilişkin grafikler ve değerleri tespit edilmiştir. Kaya (2003)'nın yaptığı çalışmaya göre geleneksel Türk kentleri için fraktal değerin 1,7 değeri civarında bulunmuş olması özellikle kent bütününün değerlendirilmesinde önemlidir. $\mathrm{Bu}$ nedenle çalışmada 1,7 değeri geleneksel Türk kentleri ve unsurları için ortalama bir değer olarak alınmıştır. Mahallelerin her biri için genel ve yeşil alana ilişkin fraktal değerler bulunmuş ve bu değerler karşılaştırmaya imkan sağlaması açısından sınıflandırılmıştır. Buna göre değerlerin sınıflandırması aşağıdaki gibidir (Çizelge 1). Bu sınıflandırma için en yüksek ve en düşük fraktal değerler arasındaki fark, beş eşit aralık oluşturacak şekilde bölünmüş, fraktal değeri düşüklük veya yüksekliğine göre sınıflandırma yapılmıştır.

Yukarıdaki sınıflandırmaya konu olan tanımlama ve değerler yükseldikçe kompleks yapı, homojen dağılım, yoğunluk, estetik, fonksiyonellik, miktar, karakteristik yapı, alan kullanımlarındaki etkinlik, sirkülasyon, organik yapı, çeşitlilik artmakta; değer düştükçe tersi gerçekleşmektedir. Ayrıca literatürlerde belirtildiği haliyle 1,7 değeri civarı geleneksel Türk kent yapısını ifade etmektedir.

Ayrıca mahallelerin karakter tayininde gözlemler, fraktal analiz sonuçları ve cbs ortamında hazırlanan haritalar ve onlardan elde edilen istatistiklere göre her mahalle için 15 farklı faktörde "yüksek, orta, düşük" nispetlerine göre değerlendirmeler yapılarak tablolar halinde hazırlanmıştır (Çizelge 2). Ayrıca çizelge 2 de bahsi geçen kriterlerin her bir mahalleden aldıkları değerlendirme doğrultusunda fonksiyon puanları tespit edilmiştir. Fonksiyon puanı, bir kriterin 26 mahallenin her birinden yüksek için 2, orta için 1 ve düşük için -1 puan değerlendirmesi ile toplamda aldığı puandır. Değerlendirme formülü;

("Yüksek" =2puan) + ("Orta" =1puan) + ("Düşük" = -1 puan $)+26$ puan $=$ Fonksiyon puanı

Eklenen 26 puan, 26 mahalle bulunması ve bir kriterin tüm mahallelerden -1 puan alması ihtimaline göre sonucun eksi çıkmasını önlemek amacıyla kullanılmıștır. $\mathrm{Bu}$ puanlamaya ilişkin değerlendirme çizelgesi çizelge 6'da verilmiştir. 
Çizelge 1. Mahalle geneline ve Yeşil alanlara ait fraktal değer aralıkları

\begin{tabular}{cccc}
\hline \multicolumn{2}{c}{ Mahalle geneli } & \multicolumn{2}{c}{ Yeşil alan } \\
\hline Fraktal değer aralığı & Tanımlama & Fraktal değer aralığı & Tanımlama \\
$<1,431$ & çok düşük & $<0,903$ & çok düşük - oldukça yetersiz \\
$1,432-1.525$ & düşük & $0,904-1,075$ & düşük - yetersiz \\
$1,526-1,619$ & orta & $1,076-1,246$ & Orta \\
$1,620-1.713$ & yüksek & $1,247-1,418$ & yüksek - yeterli \\
$1,714<$ & çok yüksek & $1,419<$ & çok yüksek - oldukça yeterli \\
\hline
\end{tabular}

Çizelge 2. Mahallelere ilişkin karakter tayininde kullanılan değerlendirme tablosu

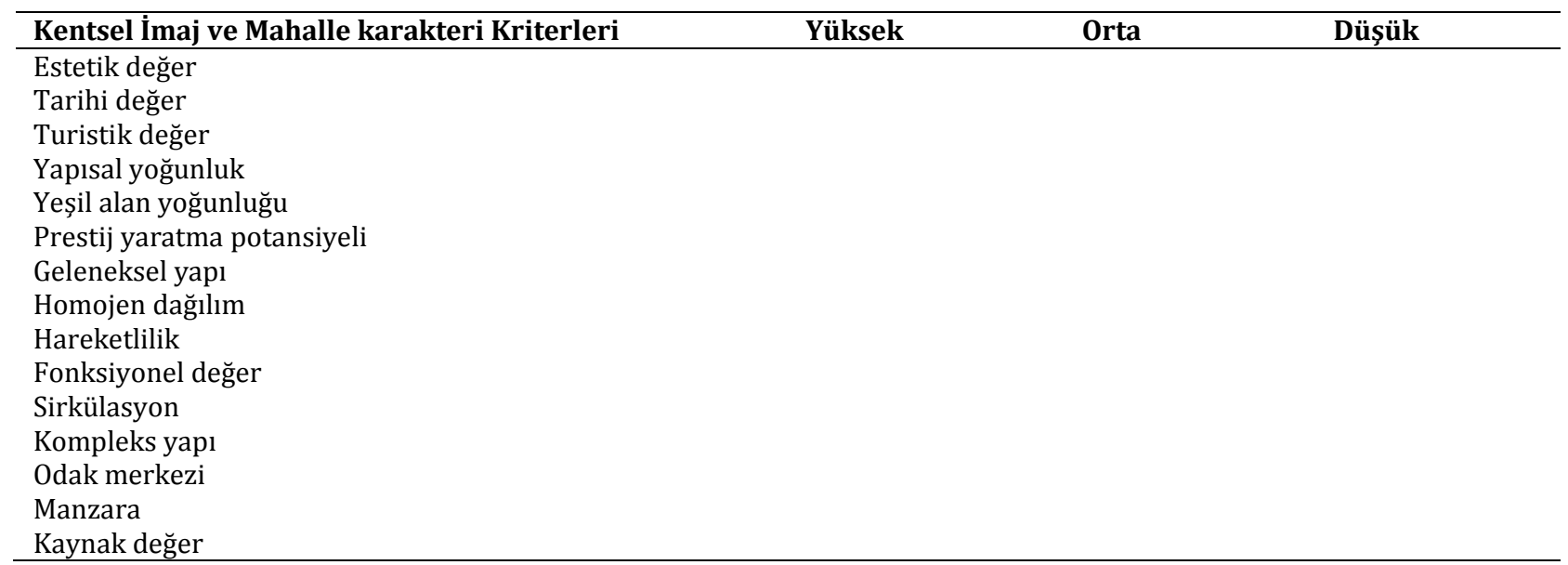

("Yüksek" =2puan) + ("Orta" =1puan) + ("Düşük" = -1puan) + 26puan = Fonksiyon puanı

\section{Bulgular ve Tartışma}

Öncelikli olarak Coğrafi Bilgi Sistemleri (CBS) ile Arcgis programında oluşturan kent haritasına kentteki tüm fonksiyonlar ve veriler girilmiştir. Böylece kentin tamamına ilişkin veriler içeren kent bütünü haritası oluşturulmuştur. Daha sonra kent 26 adet mahalleye ayrlarak mahalle bazında fonksiyonları ve verileri içeren haritalar oluşturulmuştur (şekil 1). Bu haritalarda konutlar, ticarethaneler, eğitim kurumları, yeşil alanlar, sosyal tesisler, ibadethaneler, sanayi tesisleri, kurumlar gibi kente ilișkin tüm fonksiyonlar kendi içlerinde de sınıflandırılarak işlenmiştir.

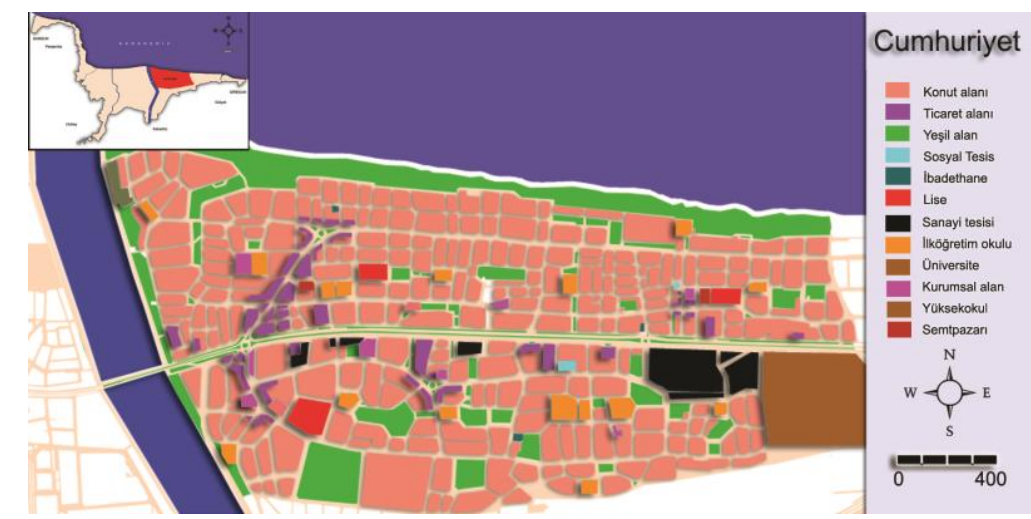

Şekil 1. 26 adet mahalle için oluşturulan haritalardan Cumhuriyet Mahallesi örneğinde alan kullanım sınıfları 


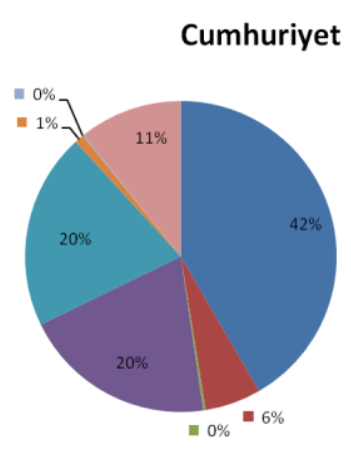

Mahalleye ilişkin bilgiler

Mahalle alanı

$: 3992992 \mathrm{~m}^{2}$

Kent geneline \% oranı

$: 13,5$

Nüfus

:5083 kiși

Kent geneline \% oranı

Şekil 2. 26 adet mahalle için çıkartılan istatistiki sonuçlara göre fonksiyonların \% dağılımları ve Cumhuriyet Mahallesi örneği

Bu yöntem ile kentlerde kentsel karakteri belirleyici önemli rol oynayan kentsel fonksiyonların her birinin kapladığı alanlar ve miktarlarına ilişsin bilgiler de istatistiki olarak çıkartılmıştır (Şekil 2). Böylece tüm fonksiyonların mahalle bazında diğer fonksiyonlara oranla ne kadar alan kapladığına ilişkin bilgiler oluşturulmuştur. Böylece her mahallede ağırlıklı olan fonksiyon(lar) tespit edilmiştir.

Ayrıca mahallelerin bir birleriyle karşılaștırılmasına ek veri sağlaması ve farklı bir bakış açısıyla mahallere ilişkin verilerin derlenmesi amacıyla fraktal analiz uygulanmıştır (Şekil 3). 26 Adet mahallenin her biri için ikişer adet haritası hazırlanmıştır; birincisi mahallelerin tüm fonksiyonlarını içeren, ikincisi de sadece yeşil alanlarını içeren haritalarıdır. Böylece her mahallenin ikișer adet haritasına uygulanan fraktal analiz sonucunda her mahalleye ait mahalle geneli ve mahalle yeşil alanlarına ait iki adet fraktal değer elde edilmiştir.

Elde edilen bu değerler mahallelerin birbirleriyle mukayesesinde ve kentsel yapısal peyzaj karakterin tayininde değerlendirilmiştir. Çalışma kapsamında alan kullanımları belirlenmiş ve kategorilere ayrılarak incelenmiştir.

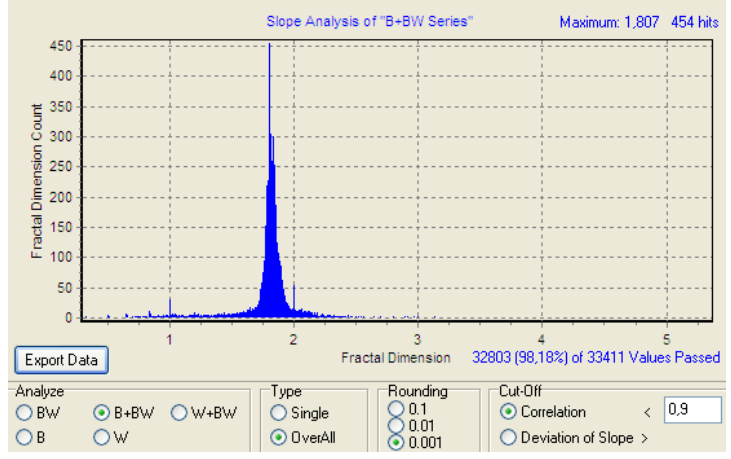

Mahalle geneli fractal değeri; $\mathbf{1 , 8 0 7}$

(Çok yüksek)

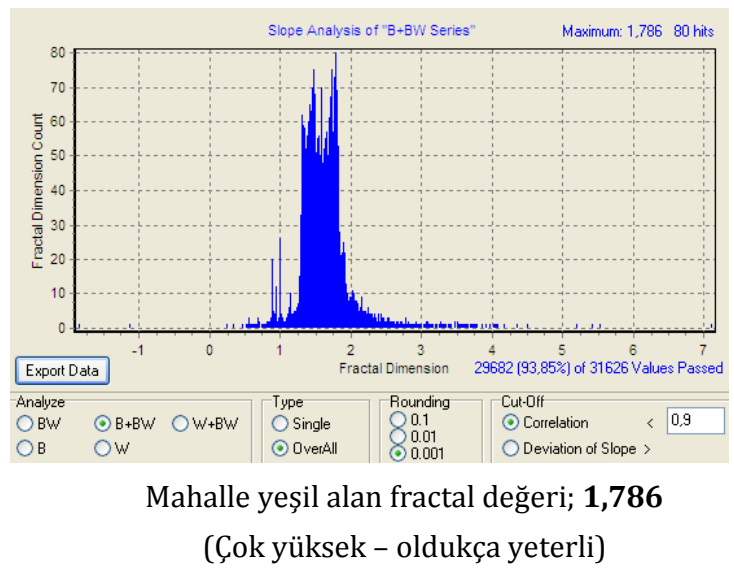

Şekil 3. 26 adet mahalle için yapılan fraktal analize ilişkin Cumhuriyet Mahallesi örneğinde analiz grafikleri.

Alan kullanımları CBS ile hazırlanan haritalardan elde edilmiştir. $\mathrm{Bu}$ alan kullanımlarının toplam alanları, kentin geneline oranları gibi değerler başlangıç verilerini vermektedir. Bu verilere göre kentte en geniş yayılım gösteren alan kullanımı konut parselleridir, bunu ise yollar ve otopark alanları takip etmektedir (Çizelge 3, Șekil 4).

Çizelge 3. Ordu kenti mevcut alan kullanımlarının alansal dağılımı

\begin{tabular}{lc}
\hline Kategori & Toplam Alan $\left(\mathbf{m}^{\mathbf{2}}\right)$ \\
\hline Konut parselleri & 7284161 \\
Kurumsal alanlar & 654269 \\
Eğitim kurumları & 803046 \\
Ticaret bölgeleri & 1452288 \\
Sağlık alanları & 111905 \\
Sosyal tesisler & 91090 \\
Yeșil alanlar & 3867001 \\
Yollar & 4368169 \\
Tarihi yapı parselleri & 25017 \\
\hline
\end{tabular}




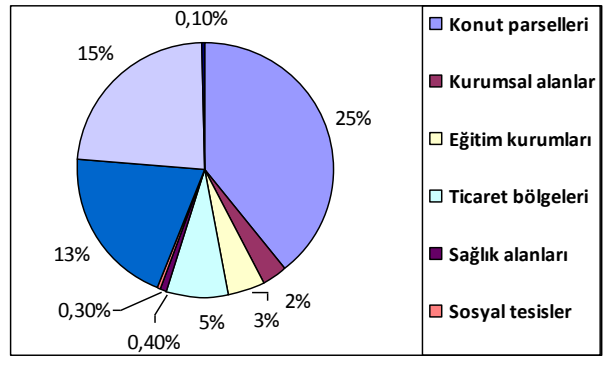

Şekil 4. Kentteki mevcut alan kullanımlarının \% olarak oransal dağılımı

Kent geneli göz önüne alınarak yapılan değerlendirme sonucunda \%25'lik oran ile konut alanlarının kentte en geniş alanı kapladıkları ortaya çıkmıştır. Bunun yanında \%15'lik kısmını kentteki bütün sokak, cadde, bulvar ve otoyolu kapsayan yol sistemi oluşturmuş, \%13'lük kısmını da yeşil alanlar teşkil etmiştir. Kentte en düşük oranlarda bulunan alan kullanımları ise \%0,30 ve \%0,40 ile çeşitli kamu kurum ve kuruluşlarına ait sosyal tesisler ile hastane ve sağlı ocaklarını kapsayan sağlı tesisleri olmuştur.

Kentte, mücavir alan sınırları içerisinde nüfusları 482 ile 16947 kişi, alanları ise 8,9ha ile 399,3ha arasında değişim gösteren 26 adet mahalle bulunmaktadır. $\mathrm{Bu}$ mahalleler, nüfusları ve kapladıkları alanlardaki değişimlerin yanı sıra bulundurdukları alan kullanımlarıyla da farklılıklar göstermektedir. Bazı mahalleler konut yerleșimi açısından yoğunluk gösterirken, bazı mahalleler ticari alan kullanımlarıyla, bazıları kurumsal, bazıları da tarihi alan kullanımlarıla ön plana çıkmaktadırlar.

Çizelge 4 incelendiğinde mahallelerdeki yoğunluğun özellikle konutlar, yollar ve yeşil alanlarda ortaya çıktığı görülmektedir. Bazı mahallelerde bunlara ek olarak ticaret alanları, kurumlar, eğitim alanları, sosyal tesisler ve tarihi alanlar da yer almaktadır. $\mathrm{Bu}$ kapsamda konut, yol ve yeşil alanların dışında kalan fonksiyonlar mahallelerde belirleyici ve yönlendirici etkiye sahiptir. Dolayısıyla mahallelerin karakterlerini tayin etmekte önemli etkenlerdir.

$\mathrm{Bu}$ istatistiki veriler ve değerlendirmelerin dışında ayrıca fraktal analiz ile mahalle bazlı değerlendirme ve karşılaştırmalar gerçekleştirilmiştir. Mahallelere ait fraktal değerler tespit edilmiş ve yöntemde anlatıldığı şekilde, karşılaştırma için sınıflandırma yapılmıştır.

Bu sınıflandırma ışığı dahilinde mahaller için analiz sonucunda belirlenen, mahalledeki tüm fonksiyonları kapsayan şekliyle mahalle geneline ve mahalle yeşil alanlarına ait fraktal değerler aşağıdaki gibidir (Çizelge 5).Mahallelerin haritalarına ilişkin gerçekleştirilen fraktal analiz sonucuna göre mahalle geneli için 26 mahalleden 18'i çok yüksek ve yüksek değerlere sahiptir. Yeşil alana ilişkin fraktal analiz sonuçlarına göre ise 26 mahalleden 14'ü çok yüksek ve yüksek değerlere sahiptir. Bu oranlar kentin yaklaşık yarısına karşılık gelmektedir.

Ayrıca kentsel yapı üzerine etkili çeşitli kentsel imaj kriterleri açısından mahallelerin değerlendirmeleri ve değerlendirme sonucunda her kriterin aldığ fonksiyon puanına ilişkin analiz sonuçları Çizelge 6 'da verilmiștir. Bu değerlendirmenin yapılmasında cbs ile hazırlanan haritalardan elde edilen istatistiki veriler, fraktal analiz sonuçları ve alan gözlemleri etkili olmuştur.

\section{Tartışma ve Sonuç}

Ordu kenti kentsel yapısına ilişkin gerçekleştirilen mevcut durum analizi, sayısal haritaların hazırlanması, istatistiki bilgilerin değerlendirilmesi ve fraktal analiz ile kentin karakterine, fonksiyonların kullanımı ve dağılımına ve genel kent yapısı adına önemli sonuçlar bulunmuştur.

Oluşturulan sayısal haritalar üzerinden coğrafi bilgi sistemleri kullanılarak kentteki fonksiyon ve alan kullanımlarına ilişkin pek çok bilgi tespit edilmiştir. $\mathrm{Bu}$ bilgiler coğrafi bilgi sistemlerinde çizim ve veri girişi ile bu çalışma kapsamında oluşturulan haritalardan elde edilen istatistiki verilerdir.

$\mathrm{Bu}$ bilgiler kentteki tüm alan kullanımlarını kapsamakta ve bu alan kullanımlarına ilişkin sayı, en küçük ve en büyük parsel değerleri ile o alan kullanımına ilişkin toplam alan büyüklüğü veya uzunluğunu vermektedir. Bu bilgilere göre kentte en geniş yayılım gösteren alan kullanımı konut yerleşimlerdir.

Konut yerleșimlerini takiben de yeşil alanların en geniş yayılım gösterdiği tespit edilmiştir. Bu da Ordu kentin temel de bir yerleşim bölgesi özelliği gösterdiğini ve yeșil alanların da kentin karakter ve imajını tanımlamada etkili olduğunu göstermektedir. Çizelge 5 'ten hazırlanan tablo sonucunda ortaya çıkan puanlamalar ile kentsel imaj kriterlerinin değerlendirmesi ve dolayısıyla kent geneline ait karakter puanları aşağıdaki tabloda belirtilmiştir.

$\mathrm{Bu}$ değerlendirme ile parçadan bütüne gitmek suretiyle önce mahallere ilişkin veriler derlenmiş, mahallelerden yola çıkllarak kent bütününe ait kentsel yapısal peyzaj karakter değerlendirmesine ulaşılmıștır. 
Çizelge 4. Mahallelerdeki alan kullanımlarının dağılımı

\begin{tabular}{|c|c|c|c|c|c|c|c|c|}
\hline & $\begin{array}{l}\text { Konut } \\
(\%)\end{array}$ & $\begin{array}{l}\text { Ticaret } \\
\text { Sanayi (\%) }\end{array}$ & $\begin{array}{l}\text { Eğitim } \\
(\%)\end{array}$ & $\begin{array}{l}\text { Tarih } \\
(\%)\end{array}$ & $\begin{array}{l}\text { Kurum } \\
(\%)\end{array}$ & $\begin{array}{l}\text { Yol } \\
\text { Otopark (\%) }\end{array}$ & $\begin{array}{l}\text { Yeşil } \\
\text { Alan (\%) }\end{array}$ & $\begin{array}{l}\text { Sosyal } \\
\text { Tesis (\%) }\end{array}$ \\
\hline Kumbaşı & 38 & 2 & 2 & & & 27 & 30 & 1 \\
\hline Güzelyalı & 40 & & 3 & & & 25 & 32 & \\
\hline Kirazlimanı & 38 & & 1 & & & 23 & 38 & \\
\hline Taşbaşı & 33 & 2 & & 3 & & 34 & 27 & 1 \\
\hline Zaferimilli & 44 & 4 & 3 & 7 & & 33 & 9 & \\
\hline Aziziye & 59 & 3 & & 2 & & 32 & 4 & \\
\hline Saray & 31 & & 5 & 2 & 15 & 23 & 24 & \\
\hline Düz & 1 & 26 & 1 & 2 & 4 & 39 & 25 & 2 \\
\hline Selimiye & 53 & 2 & 2 & & & 37 & 5 & 1 \\
\hline Şarkiye & & 32 & 2 & & 5 & 44 & 16 & 1 \\
\hline Nizamettin & 52 & & 11 & & & 27 & 10 & \\
\hline Bucak & 48 & 3 & 7 & 4 & & 31 & 7 & \\
\hline Şahincili & 51 & & 3 & & & 24 & 19 & \\
\hline Subaşı & 57 & 4 & 2 & & & 33 & 4 & \\
\hline Yeni & 38 & 16 & 5 & & & 33 & 7 & 1 \\
\hline Şirinevler & 46 & 3 & 3 & & 2 & 28 & 18 & \\
\hline Bahçelievler & 25 & 6 & 8 & & 5 & 25 & 30 & 1 \\
\hline Akyazı & 41 & 1 & 5 & & 6 & 25 & 18 & 1 \\
\hline Karacaömer & 49 & & 2 & & & 28 & 20 & 1 \\
\hline Eskipazar & 19 & 12 & 1 & & 22 & 12 & 34 & \\
\hline Karşıyaka & 43 & 1 & 3 & & 11 & 23 & 19 & \\
\hline Karapınar & 14 & 41 & 1 & & 2 & 19 & 22 & 1 \\
\hline Durugöl & 35 & 14 & 1 & & 10 & 24 & 16 & \\
\hline Cumhuriyet & 42 & 6 & 11 & & 1 & 20 & 20 & \\
\hline Akçatepe & 53 & & 6 & & 1 & 25 & 14 & \\
\hline Turnasuyu & 42 & 5 & 3 & & & 21 & 29 & \\
\hline
\end{tabular}

Çizelge 5. Mahallelerin geneline ve yeşil alanlarına ait fraktal analiz değerleri

\begin{tabular}{|c|c|c|c|c|}
\hline & Genel & & Yeşil al & \\
\hline & Değer & Aralık & Değer & Aralık \\
\hline Kumbaşı & 1,596 & Orta & 1,501 & Çok yüksek - oldukça yeterli \\
\hline Güzelyalı & 1,618 & Orta & 1,166 & Orta \\
\hline Kirazlimanı & 1,610 & Orta & 1,085 & Orta \\
\hline Taşbaşı & 1,771 & Çok yüksek & 1,283 & Yüksek - yeterli \\
\hline Zaferimilli & 1,797 & Çok yüksek & 0,903 & Çok düşük - oldukça yetersiz \\
\hline Aziziye & 1,619 & Orta & 0 & Çok düşük - oldukça yetersiz \\
\hline Saray & 1,583 & Orta & 0 & Çok düşük - oldukça yetersiz \\
\hline Düz & 1 & Çok düşük & 1,384 & Yüksek - yeterli \\
\hline Selimiye & 1,728 & Çok yüksek & 0 & Çok düşük - oldukça yetersiz \\
\hline Şarkiye & 1,691 & Yüksek & 1,477 & Çok yüksek - oldukça yeterli \\
\hline Nizamettin & 1,696 & Yüksek & 0 & Çok düşük - oldukça yetersiz \\
\hline Bucak & 1,725 & Çok yüksek & 0,967 & Düşük - yetersiz \\
\hline Şahincili & 1,739 & Çok yüksek & 1,589 & Çok yüksek - oldukça yeterli \\
\hline Subaşı & 1,633 & Yüksek & 0 & Çok düşük - oldukça yetersiz \\
\hline Yeni & 1,667 & Yüksek & 1,116 & Orta \\
\hline Şirinevler & 1,676 & Yüksek & 1,388 & Yüksek - yeterli \\
\hline Bahçelievler & 1,664 & Yüksek & 1,352 & Yüksek - yeterli \\
\hline Akyazı & 1,848 & Çok yüksek & 2 & Çok yüksek - oldukça yeterli \\
\hline Karacaömer & 1,736 & Çok yüksek & 1,362 & Yüksek - yeterli \\
\hline Eskipazar & 1,431 & Çok düşük & 1,195 & Orta \\
\hline Karşıyaka & 1,781 & Çok yüksek & 1,548 & Çok yüksek - oldukça yeterli \\
\hline Karapınar & 1,640 & Yüksek & 1,506 & Çok yüksek - oldukça yeterli \\
\hline Durugöl & 1,769 & Çok yüksek & 1,325 & Yüksek - yeterli \\
\hline Cumhuriyet & 1,807 & Çok yüksek & 1,786 & Çok yüksek - oldukça yeterli \\
\hline Akçatepe & 1,529 & Orta & 1,386 & Yüksek - yeterli \\
\hline Turnasuyu & 1,762 & Çok yüksek & 1,382 & Yüksek - yeterli \\
\hline
\end{tabular}


Çizelge 6. Mahallelerin fonksiyonlara ve fonksiyonun mahalledeki etkinliğine göre dağılımı

\begin{tabular}{|c|c|c|c|c|c|c|}
\hline $\begin{array}{c}\text { Kentsel İmaj } \\
\text { Kriterleri }\end{array}$ & \multicolumn{2}{|c|}{ Yüksek } & Orta & \multicolumn{2}{|c|}{ Düşük } & $\begin{array}{c}\text { Fonksiyon } \\
\text { Puanı }\end{array}$ \\
\hline Estetik değer & $\begin{array}{c}\text { Taşbaşı } \\
\text { Zaferimilli } \\
\text { Aziziye } \\
\text { Selimiye } \\
\text { Şarkiye } \\
\text { Nizamettin } \\
\text { Bucak } \\
\text { Şahincili } \\
\text { Subaşı } \\
\end{array}$ & $\begin{array}{c}\text { Yeni } \\
\text { Şirinevler } \\
\text { Bahçelievler } \\
\text { Akyazı } \\
\text { Karacaömer } \\
\text { Karşıyaka } \\
\text { Durugöl } \\
\text { Cumhuriyet } \\
\text { Turnasuyu } \\
\end{array}$ & $\begin{array}{l}\text { Kumbaşı } \\
\text { Güzelyalı } \\
\text { Saray } \\
\text { Düz } \\
\text { Akçatepe }\end{array}$ & \multicolumn{2}{|c|}{$\begin{array}{l}\text { Kirazlimanı } \\
\text { Eskipazar } \\
\text { Karapınar }\end{array}$} & 64 \\
\hline Tarihi değer & \multicolumn{2}{|c|}{$\begin{array}{c}\text { Taşbaşı } \\
\text { Zaferimilli } \\
\text { Aziziye }\end{array}$} & $\begin{array}{c}\text { Saray } \\
\text { Düz }\end{array}$ & $\begin{array}{c}\text { Kumbaşı } \\
\text { Güzelyalı } \\
\text { Kirazlimanı } \\
\text { Selimiye } \\
\text { Şarkiye } \\
\text { Nizamettin } \\
\text { Bucak } \\
\text { Şahincili } \\
\text { Subaşı } \\
\text { Yeni } \\
\text { Șirinevler } \\
\end{array}$ & $\begin{array}{c}\text { Bahçelievler } \\
\text { Akyazı } \\
\text { Karacaömer } \\
\text { Eskipazar } \\
\text { Karşıyaka } \\
\text { Karapınar } \\
\text { Durugöl } \\
\text { Cumhuriyet } \\
\text { Akçatepe } \\
\text { Turnasuyu }\end{array}$ & 13 \\
\hline Turistik değer & \multicolumn{2}{|c|}{$\begin{array}{c}\text { Taşbaşı } \\
\text { Zaferimilli } \\
\text { Aziziye }\end{array}$} & $\begin{array}{c}\text { Saray } \\
\text { Düz } \\
\text { Şarkiye } \\
\text { Bahçelievler } \\
\text { Akyazı } \\
\text { Turnasuyu }\end{array}$ & $\begin{array}{c}\text { Kumbaşı } \\
\text { Güzelyalı } \\
\text { Kirazlimanı } \\
\text { Selimiye } \\
\text { Nizamettin } \\
\text { Bucak } \\
\text { Şahincili } \\
\text { Subaşı }\end{array}$ & $\begin{array}{c}\text { Yeni } \\
\text { Şirinevler } \\
\text { Karacaömer } \\
\text { Eskipazar } \\
\text { Karşıyaka } \\
\text { Karapınar } \\
\text { Durugöl } \\
\text { Cumhuriyet } \\
\text { Akçatepe } \\
\end{array}$ & 21 \\
\hline Yapısal yoğunluk & $\begin{array}{c}\text { Güzelyalı } \\
\text { Kirazlimanı } \\
\text { Taşbaşı } \\
\text { Zaferimilli } \\
\text { Aziziye } \\
\text { Saray } \\
\text { Selimiye } \\
\text { Şarkiye } \\
\text { Nizamettin } \\
\text { Bucak } \\
\text { Şahincili }\end{array}$ & $\begin{array}{c}\text { Subaşı } \\
\text { Yeni } \\
\text { Şirinevler } \\
\text { Bahçelievler } \\
\text { Akyazı } \\
\text { Karacaömer } \\
\text { Karşıyaka } \\
\text { Karapınar } \\
\text { Durugöl } \\
\text { Cumhuriyet } \\
\text { Turnasuyu }\end{array}$ & $\begin{array}{l}\text { Kumbaşı } \\
\text { Düz } \\
\text { Eskipazar } \\
\text { Akçatepe }\end{array}$ & & & 74 \\
\hline $\begin{array}{c}\text { Yeşil alan } \\
\text { yoğunluğu }\end{array}$ & \multicolumn{2}{|c|}{$\begin{array}{c}\text { Bahçelievler } \\
\text { Akyazı } \\
\text { Karşıyaka } \\
\text { Cumhuriyet }\end{array}$} & $\begin{array}{c}\text { Kumbaşı } \\
\text { Şarkiye } \\
\text { Şahincili } \\
\text { Karacaömer } \\
\text { Eskipazar } \\
\text { Karapınar } \\
\text { Durugöl } \\
\text { Akçatepe } \\
\text { Turnasuyu }\end{array}$ & $\begin{array}{c}\text { Güzelyalı } \\
\text { Kirazlimanı } \\
\text { Taşbaşı } \\
\text { Zaferimilli } \\
\text { Aziziye } \\
\text { Saray } \\
\text { Düz }\end{array}$ & $\begin{array}{c}\text { Selimiye } \\
\text { Nizamettin } \\
\text { Bucak } \\
\text { Subaşı } \\
\text { Yeni } \\
\text { Şirinevler } \\
\text { Karacaömer } \\
\text { Karşıyaka }\end{array}$ & 28 \\
\hline $\begin{array}{c}\text { Prestij yaratma } \\
\text { potansiyeli }\end{array}$ & $\begin{array}{c}\text { Kumbaşı } \\
\text { Güzelyalı } \\
\text { Kirazlimanı } \\
\text { Taşbaşı } \\
\text { Zaferimilli } \\
\text { Aziziye }\end{array}$ & $\begin{array}{c}\text { Düz } \\
\text { Bahçelievler } \\
\text { Akyazı } \\
\text { Eskipazar } \\
\text { Cumhuriyet } \\
\text { Turnasuyu }\end{array}$ & $\begin{array}{c}\text { Saray } \\
\text { Selimiye } \\
\text { Şarkiye } \\
\text { Nizamettin } \\
\text { Bucak } \\
\text { Şirinevler } \\
\text { Durugöl }\end{array}$ & $\begin{array}{r}\text { Sa } \\
\mathrm{S} \\
\mathrm{Ka} \\
\mathrm{Al}\end{array}$ & $\begin{array}{l}\text { icili } \\
\text { așı } \\
\text { ai } \\
\text { Inar } \\
\text { cepe }\end{array}$ & 52 \\
\hline Geleneksel yapı & $\begin{array}{c}\text { Taşbaşı } \\
\text { Zaferimilli } \\
\text { Selimiye } \\
\text { Şarkiye } \\
\text { Nizamettin } \\
\text { Bucak } \\
\text { Şahincili } \\
\text { Subaşı }\end{array}$ & $\begin{array}{c}\text { Yeni } \\
\text { Şirinevler } \\
\text { Bahçelievler } \\
\text { Akyazı } \\
\text { Karacaömer } \\
\text { Karşıyaka } \\
\text { Durugöl } \\
\text { Cumhuriyet } \\
\text { Turnasuyu }\end{array}$ & $\begin{array}{c}\text { Güzelyalı } \\
\text { Kirazlimanı } \\
\text { Aziziye } \\
\text { Saray } \\
\text { Eskipazar } \\
\text { Akçatepe }\end{array}$ & & $\begin{array}{l}\text { başı } \\
\mathrm{z} \\
\text { inar }\end{array}$ & 63 \\
\hline
\end{tabular}




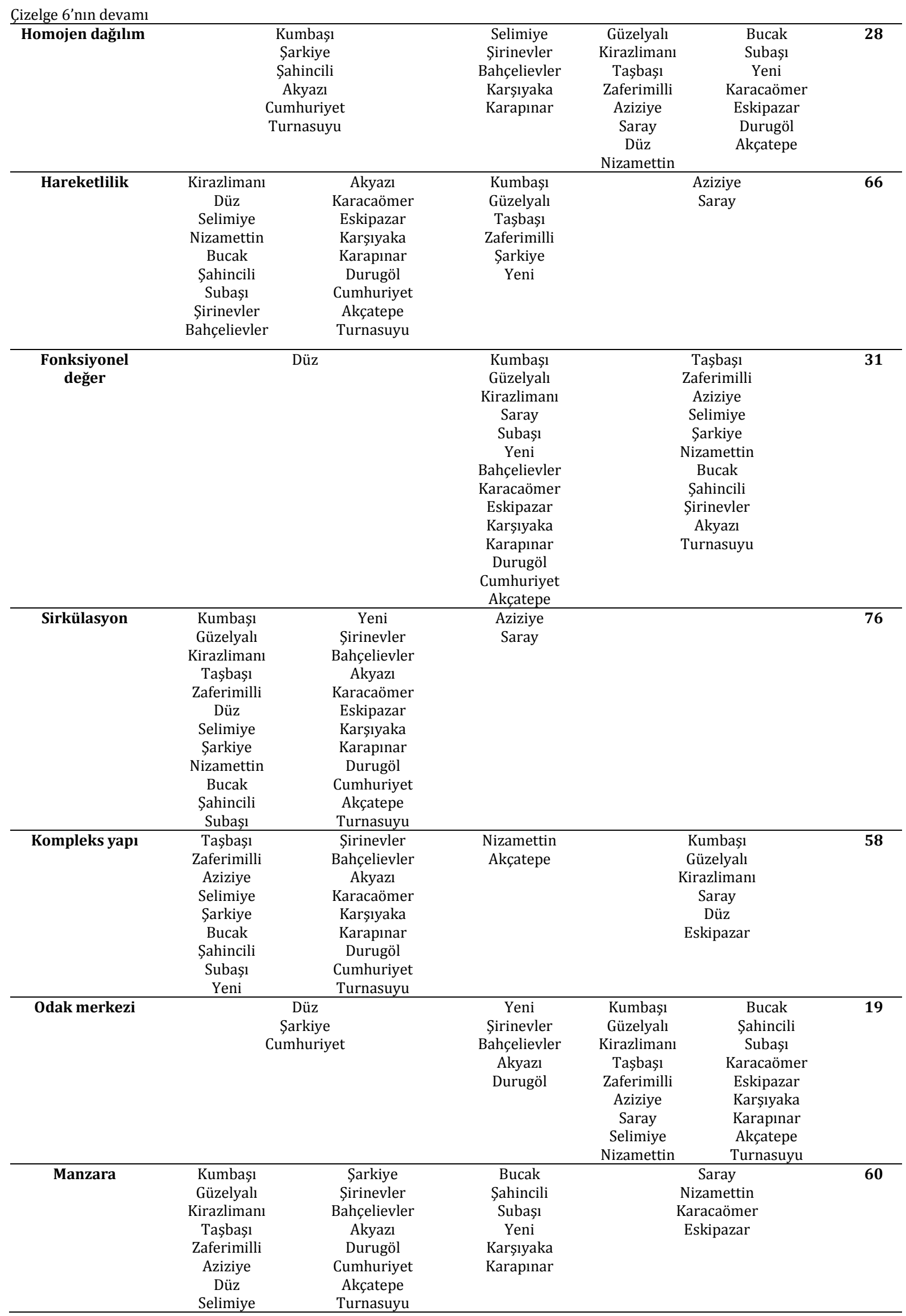




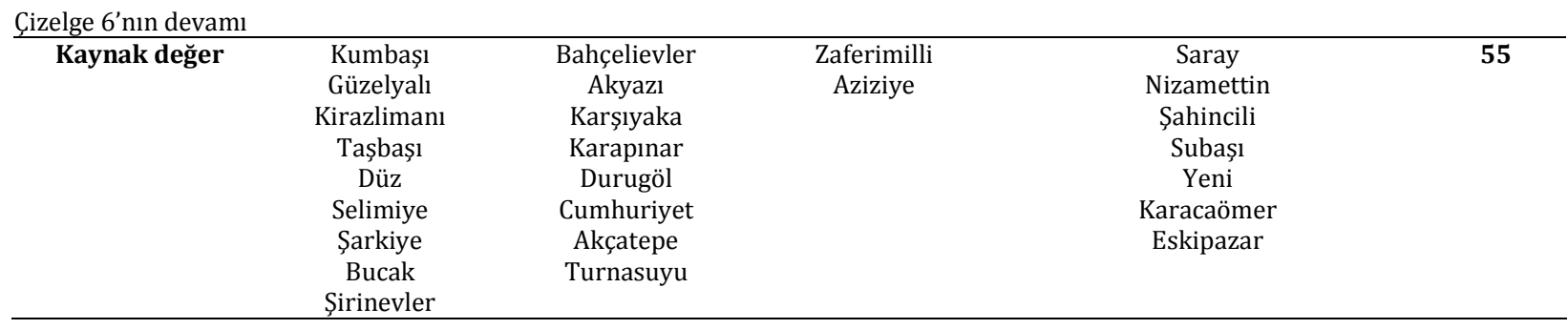

Buna göre Ordu kenti sirkülasyon açısından güçlü, estetik, ancak yapısal yoğunluğu yüksek bir kenttir. Tarihi kullanımlar açısından odak merkezi niteliği bakımından, turistik kullanımlar açısından ve kent içi yeşil alan yoğunluğu bakımından $\begin{array}{llll}\text { yetersizliklerinin bulunduğu Çizelge } 7 & \end{array}$ incelendiğinde görülmektedir.

Mahallelerin kentsel imaj kriterleri açısından değerlendirilmesi ve kriterlerden elde ettikleri toplam değerlere göre mahallelerin puanları belirlenmiştir (Çizelge 8). Bu puanlar mahallelerin bir birleriyle mukayesesine olanak sağlamaktadır. Buna göre bütün kriterler değerlendirildiğinde en yüksek puanı Bahçelievler ve Cumhuriyet Mahalleleri almıştır. En düşük puanları ise Saray ve Eskipazar Mahalleleri almıştır. Bu sonuç yüksek puan alanların kentsel kriterler bakımından daha donanıml, daha komplike mahalleler olduğunu ortaya koyarken düşük puanlı mahallelerin tam tersi durum sergilediğini göstermektedir.

Çizelge 7. Kent geneline ait yapısal peyzaj karakter puanları

\begin{tabular}{lclllc}
\hline Kriter & Puan & Kriter & Puan & Kriter & Puan \\
\hline Sirkülasyon & 76 & Manzara & 60 & Homojen dağlım & 28 \\
Yapısal yoğunluk & 74 & Kompleks yapı & 58 & Yeşil alan yoğunluğu & 28 \\
Hareketlilik & 66 & Kaynak değer & 55 & Turistik değer & 21 \\
Estetik değer & 64 & Prestij yaratma potansiyeli & 52 & Odak merkezi & 19 \\
Geleneksel yapı & 63 & Fonksiyonel değer & 31 & Tarihi değer & 13 \\
\hline
\end{tabular}

Çizelge 6'dan derlenmiștir.

Çizelge 8. Karakter analiz tablolarına göre mahallelerin puanları

\begin{tabular}{llllll}
\hline Mahalle & Puan & Mahalle & Puan & Mahalle & Puan \\
\hline Bahçelievler Mah. & 23 & Karşıyaka Mah. & 15 & Yeni Mah. & 8 \\
Cumhuriyet Mah. & 23 & Düz Mah. & 14 & Güzelyalı Mah. & 8 \\
Akyazı Mah. & 22 & Selimiye Mah. & 13 & Subaşı Mah. & 7 \\
Şarkiye Mah. & 20 & Aziziye Mah. & 12 & Kirazlimanı Mah. & 7 \\
Turnasuyu Mah. & 19 & Kumbaşı Mah. & 10 & Karacaömer Mah & 7 \\
Durugöl Mah. & 17 & Bucak Mah. & 10 & Nizamettin Mah. & 4 \\
Taşbaşı Mah. & 17 & Şahincili Mah. & 10 & Saray Mah. & 2 \\
Zaferimilli Mah. & 16 & Akçatepe Mah. & 9 & Eskipazar Mah. & 2 \\
Şirinevler Mah. & 15 & Karapınar Mah. & 8 & &
\end{tabular}

Çizelge 2'nin değerlendirilmesine göre; (Yüksek=2p) + (Orta=1p) + (Düşük=-1p) = Puan 
Kent geneli, yeşil alan ve yol fraktal değerleri $(1,489$; 1,490; 1,506) ortalama saylabilecek değerlerdedirler. Bu nedenle duruma ilişkin yapılan yorumlar çok küçük sapmaları ifade etmektedir. Değerler büyüdükçe kompleks yapı, estetik değer, organik sistem örgüsü artacak, değerler düştükçe aksi durum gerçekleşeceğinden duruma göre değerlerin yükselmesi veya düşmesi anlamlı ve istenilen durum olabilir.
Fraktal değerlerin 0 ile 2,5'e varan değerler arasında geniş bir skalada değiştiği düşünülürse her değer bir farklılığı ifade etmekte, bu da karşılaştırmalar ile bir birine göre değişimi ve farklılığı ortaya koymaktadır. Kent bütününe ait fraktal değerlendirme sonucunda bulunan 1,489 değerinin geleneksel Türk kent yerleşimi için bulunan 1,7 değeri civarlarında olmadığı belirlenmiştir. (Şekil 5).

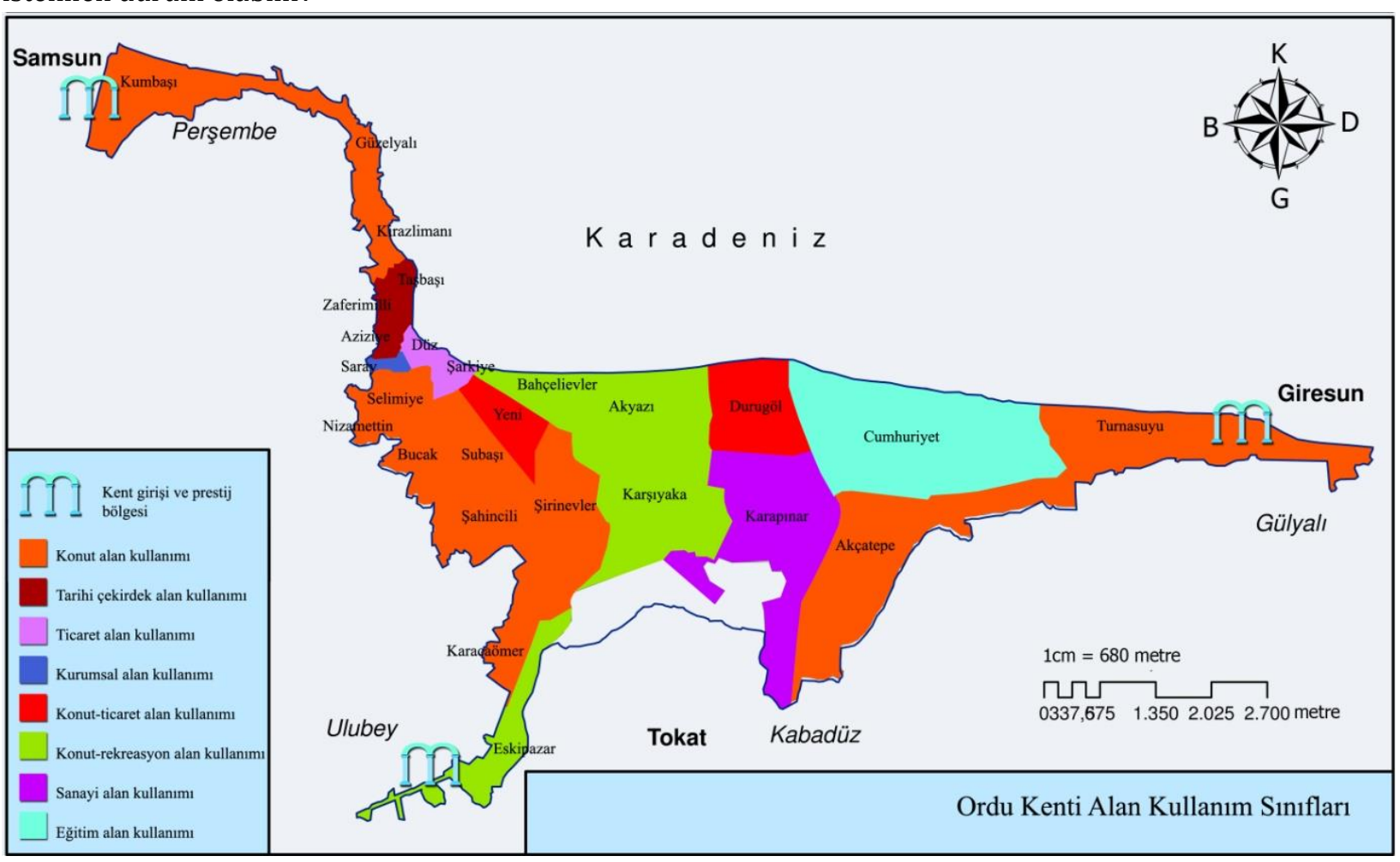

Şekil 5. Ordu kenti alan kullanımları haritası

Ayrıca mahallelere ilişkin fraktal analizlerin değerlendirilmesi sonucunda kentin bütünü baz alındığında, kentin heterojen șekilde ve kısmen kompleks, yoğun, estetik, fonksiyonel, heterojen dağılımlı, organik, çeşitlilik gösteren bir yapıya sahip olduğu, yine kısmen geleneksel ve kısmen karakteristik kent düzeni gösterdiği ortaya çlkmaktadır.

Bunun yanında Güzelyalı, Kirazlimanı, Şahincili, Şirinevler, Bahçelievler, Akyazı, Karşıyaka ve Cumhuriyet mahallerinin her iki fraktal değer sinıflandırmaları arasındaki denge nedeniyle bu mahallelerde mahalle genelindeki fonksiyonel yapı ile mahalledeki yeșil alan ilişkisinin de dengeli ve uyumlu olduğu tespit edilmiştir.

Kent bütünü, yeşil alanlar ve yol sistemlerine ait değerlerin bir birlerine yakın değerler olması ise kentin tüm fonksiyonlarıla birlikte uyumlu bir gelişim gösterdiğinin ispatıdır. Yeşil alanlara ait değerin nispeten düșük olması kentteki yeșil alan dağılımının bir miktar heterojenlik gösterdiğinin, dağllımın düzensiz olduğunun ve nispeten basit bir sistem oluşturduğunun bir ifadesidir (Şekil 6).

Mahallelere ait genel fraktal değerlerin ortalama olarak 1,7 değeri civarında olması kent bütünü fraktal değeri üzerinde bir değeri göstermektedir. $\mathrm{Bu}$ da mahallelerin kendi içlerinde nispeten yeterli, ancak tek bir sistem olarak ayrı ayrı oldukları andan daha basit, sade ve düşük estetik özelliklere sahip olduklarını ifade etmektedir.

Yeşil alanlara ilişkin değerlerin ise zaman zaman yükselmesi ve düşmesi ile ortalama değerin düşük olması kent genelinde yeşil alanların dağılımının homojen olmadığını, belirli alanlarda yoğun yeșil doku bulunurken, diğer alanlarda ise yeșil dokunun azaldığını ifade etmektedir. 

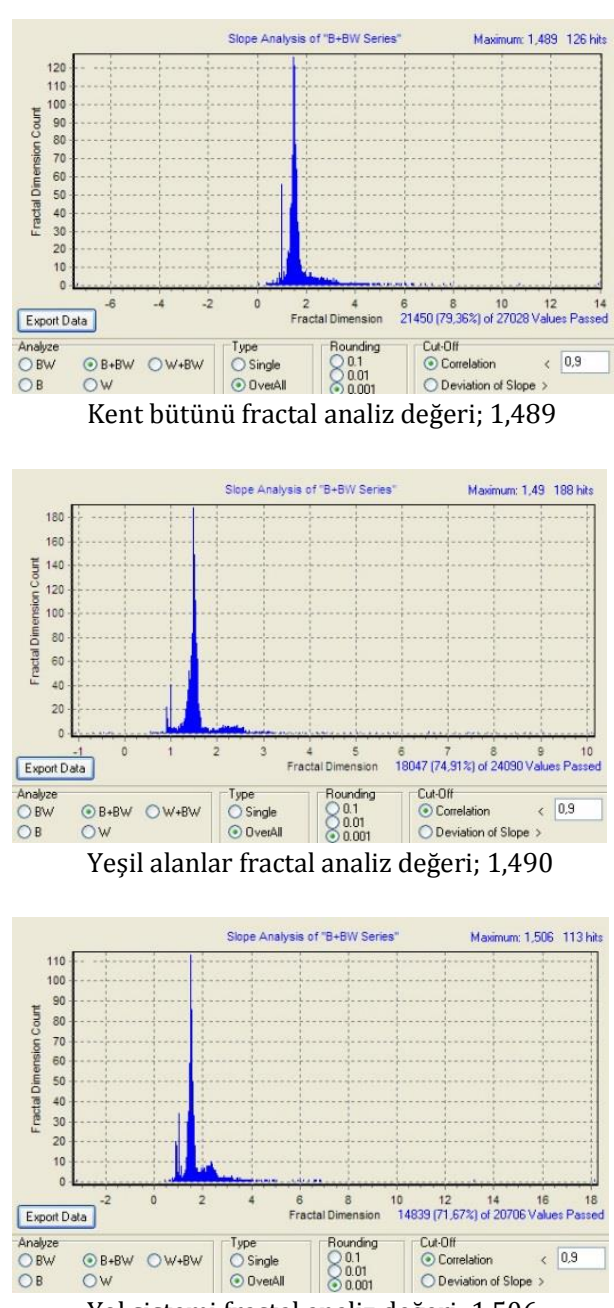

Yol sistemi fractal analiz değeri; 1,506

Şekil 6. Kente ait fraktal analiz grafikleri

\section{Kaynaklar}

Anonim, 2004. Ordu Çevre Durum Raporu, T.C. Ordu Valiliği İl Çevre ve Orman Müdürlüğü, s194, Ordu.

Anonim, 2008. Ordu Belediyesi Stratejik Planı, Ordu Belediyesi, s123, Ordu.

Anonim, 2012. Adrese Dayalı Nüfus Kayıt Sistemi Verileri. Türkiye İstatistik Kurumu.

Atik, M., Ortaçeşme, V., 2010. Peyzaj Karakter Analizi Yöntemi ile Antalya Side Bölgesi Kültürel Peyzajlarının Karakter Analizi. Tübitak Projesi, Proje No: 108Y345, Antalya.

Kaya, H., S., 2003. Kentsel Mekan Zenginliğinin Kaos Teorisi ve Fractal Geometri Kullanılarak Değerlendirilmesi. İstanbul Teknik Üniversitesi Fen Bilimleri Enstitüsü, Yüksek Lisans Tezi, s159, İstanbul.

Özgür, Ş., 2011. Akdeniz Kentlerinin Karakteristik Özelliklerinin Peyzaj Mimarlığı Açısından İrdelenmesi: Antalya Örneği. Ankara Üniversitesi Fen Bilimleri Enstitüsü,Yüksek Lisans Tezi, Ankara.

Swanwick, C. 2002. Landscape Character Assessment Guidance For England and Scotland. The Countryside Agency and Scottish Natural Heritage, 84 p., England

Wascher, D.M. 2005. European Landscape Character Areas. Information Press, Oxford, 148 p., England 